\title{
Evaluation of Anxiety Status and Reasons for Refusal of Surgical Treatment Among Patients with Non-Small Cell Lung Cancer
}

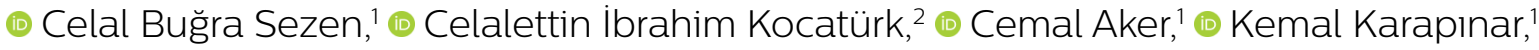

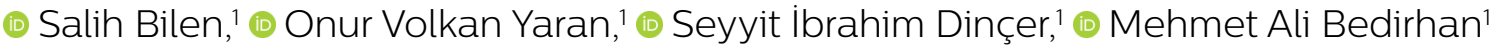

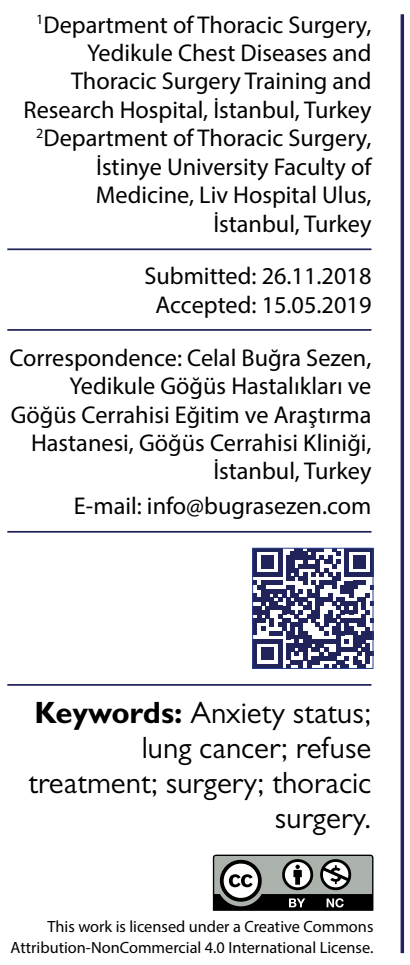

\section{ABSTRACT}

Objective: In this study, we evaluated reasons for treatment refusal and anxiety levels of patients who were diagnosed with non-small cell lung cancer in our hospital and were recommended surgery by a multidisciplinary committee but refused surgical treatment.

Methods: In this study, the records of 223 patients whose cases were reviewed by the oncology council of our hospital and were recommended for surgery were reviewed retrospectively. There were patients in Group-A who accepted surgical treatment and Group-B who refused surgical treatment. The anxiety levels of all patients were assessed using the State-Trait Anxiety Inventory (STAI).

Results: The anxiety levels of the patients in Group-B were significantly higher than anxiety levels of the patients in Group-A $(\mathrm{p}<0.00 \mathrm{I})$. Twenty-two $(68.6 \%)$ of the patients in Group-B completely refused surgery, while $10(31.3 \%)$ of the patients preferred to undergo surgery in a different center. As for the patients' reasons for refusing surgical treatment, 20 patients (62.5\%) reported high surgical risk, seven (21.9\%) of the patients felt they had not been sufficiently informed by their doctor, and five (15.6\%) of the patients reported dissatisfaction with the hospital facilities.

Conclusion: In conclusion, our findings suggest that the main reason patients refuse surgical treatment is increased anxiety following diagnosis. We believe that the doctor-patient relationship is the most essential factor in patients' adherence to treatment.

\section{INTRODUCTION}

Despite advances in diagnosis and treatment, lung cancer is still a leading cause of cancer-related deaths worldwide. Surgery is the most effective treatment option. However, only about $20 \%$ of the patients are eligible for surgery. [1] Patients who are ineligible for surgical treatment are generally patients with advanced, unresectable, and inoperable cancer. On the other hand, some patients who are eligible for surgery refuse operation and lose their best chance of treatment.

Cancer patients may exhibit mood symptoms due to psychogenic effects. Sorrow, despondency, and anhedonia may lead to depression and symptoms of anxiety, including panic, worry, and fear. ${ }^{[2,3]}$ As surgeons are primarily concerned with possible surgical complications and oncolog- ical results, assessing and determining patients' psychological state is difficult. In general, patients' preoperative anxiety is disregarded. ${ }^{[4]}$

In this study, we evaluated reasons for refusal of treatment and anxiety levels of patients who were diagnosed with non-small cell lung cancer (NSCLC) in our hospital. These patients were recommended surgery by a multidisciplinary committee but refused surgical treatment.

\section{MATERIALS AND METHODS}

The records of 223 patients whose cases were reviewed by the oncology council of our hospital between January 01 , 2016 and December 31, 2016, and were recommended for surgery were reviewed retrospectively. All patients were interviewed either by phone or face-to-face between Jan- 
uary and February 2018. The State-Trait Anxiety Inventory (STAI) was applied to all patients to assess the anxiety level. Five patients who died within the first postoperative 90 days and three who died within the first year of follow-up were excluded from this study. The remaining 215 patients were divided into two groups. Group A included I 83 patients (85.2\%) who accepted surgical treatment, and group B included 32 patients (14.8\%) who refused surgical treatment. Reasons for refusing surgery were evaluated in two categories as follows: a) patients who agreed to undergo surgery but not in our hospital and b) patients who refused surgery and preferred medical treatment.

This study was approved by the institutional review board and was conducted in accordance with the principles of the Declaration of Helsinki.

\section{Selecting and informing patients}

Surgical decisions in our hospital are made by a council. Patients are informed in detail about the planned surgeries by thoracic surgeons. This conversation takes place during a meeting with the patient and their relatives. In this meeting, patients are informed about the disease itself, available treatment options, the planned operation, possible intraoperative and postoperative complications, and mortality risk. Patients are given time to consider the matter and decide whether to undergo surgery. If the patient accepts surgical treatment, an informed consent form is prepared, and the patient is scheduled for surgery. If patients refuse surgery, they are referred to the relevant department based on their preferred treatment option.

\section{Factors affecting patients' decision to accept/ refuse surgery}

Factors evaluated in this study included patient comorbidities and associated increased risk, increased risk due to the size of planned resection, lack of health insurance and financial problems, lack of trust and communication between the patient/relatives and surgeon, dissatisfaction with hospital conditions, and patient anxiety.

Comorbidities were classified as respiratory problems (chronic obstructive lung disease), cardiac problems (arrhythmia, heart failure, post-myocardial infarction), endocrinological problems (diabetes mellitus, goiter), and nephrological problems (chronic kidney disease and acute kidney failure).

The planned operations were evaluated regarding the surgical approach (e.g., video-assisted thoracoscopic surgery [VATS] or conventional thoracotomy). The operations were analyzed in three groups: lobectomy, segmentectomy, and thoracotomy.

\section{Assessment of anxiety status}

The anxiety levels of all patients were assessed using the STAI. ${ }^{[5,6]}$ The STAI includes separate scales to measure patients' trait and state anxiety. State anxiety scores reflect an individual's level of anxiety in a certain situation, whereas trait anxiety score indicates the level of anxiety an individual feels independent of their situation. The scores obtained from both scales range from 20 to 80 . Higher scores indicate higher levels of anxiety.

\section{Statistical analysis}

Statistical analyses were performed using IBM SPSS Windows 21.0. Differences among groups were analyzed using the independent samples t-test. Anxiety levels of patients accepting and refusing surgical treatment were compared using the Kruskal-Wallis test. Level of significance was accepted as $\mathrm{p}=0.05$.

\section{RESULTS}

Of the patients included in this study, I 73 were male (80.5\%), and 42 were female (19.5\%); the mean age was $59.56 \pm 9.78$ (26-83) years. Tumors were stage I in 94 patients (43.7\%), stage II in 94 patients (43.7\%), and stage III in 27 patients (12.6\%). There was no association between patients' comorbidities and refusal of surgery. We determined that none of the patients refused surgery due to financial reasons, and all had social security. The patients' demographic characteristics and clinical stages are shown in Table I.

Twenty-two (68.6\%) of the patients in group B completely refused surgery, while $10(31.3 \%)$ preferred to undergo surgery in a different center. As for the patients' reasons for refusing surgical treatment, 20 patients (62.5\%) cited high surgical risk, seven (21.9\%) felt they had not been sufficiently informed by their doctor, and five (15.6\%) reported dissatisfaction with the hospital facilities.

Table I. Demographic characteristics of the patients

\begin{tabular}{lccc}
\hline Variables & Group A & Group B & p \\
\hline $\begin{array}{l}\text { Gender, n (\%) } \\
\quad \text { Male }\end{array}$ & $150(82)$ & $23(71.9)$ & 0.184 \\
$\quad$ Female & $33(18)$ & $9(28.1)$ & \\
Age, mean \pm SD & $59.67 \pm 9.1$ & $58.94 \pm 12.8$ & 0.817 \\
$\quad \leq 65$ & $133(72.7)$ & $22(68.8)$ & 0.648 \\
$>65$ & $50(27.3)$ & $10(31.3)$ & \\
Operation side, n (\%) & & & \\
$\quad$ Right & $108(59)$ & $23(71.9)$ & 0.169 \\
$\quad$ Left & $75(4 I)$ & $9(28.1)$ & \\
Comorbidity, n (\%) & $66(36.1)$ & $14(43.8)$ & 0.407 \\
$\quad$ Cardiac problems & $23(12.6)$ & $11(34.4)$ & $>0.05$ \\
$\quad$ Respiratory problems & $28(15.3)$ & $7(21.9)$ & \\
$\quad$ Endocrinological & & & \\
problems & $9(4.9)$ & $3(9.4)$ & \\
$\quad$ Nephrological problems & I (0.5) & I (3.I) & \\
Clinical stage, n (\%) & & & \\
I & $78(42.6)$ & $16(50)$ & 0.465 \\
2 & $80(43.7)$ & $14(43.8)$ & \\
3 & $25(13.7)$ & $2(6.3)$ & \\
\hline
\end{tabular}

SD: Standard deviation. 
In group A, 142 patients (77.6\%) underwent lobectomy. The most common procedure was upper right lobectomy $(n=45,24.6 \%)$. In group $B$, lobectomy was planned for 23 patients $(68.8 \%)$, pneumonectomy for six ( $18.8 \%)$ patients, and segmentectomy for three $(9.4 \%)$ patients. The most commonly planned procedure in group B was lower right lobectomy (28.1\%). There were significant differences between groups $A$ and $B$ in terms of surgical approach and type of operation planned (Table 2).

Within-group B, there was no significant differences in comorbidities, surgical approach, type of planned resection, or anxiety status between the patients who preferred to have surgery in another institution and the patients who completely refused surgery (Table 3 ).

Assessment of anxiety levels using the STAI showed that the patients in group $B$ had a mean state anxiety score of 47.I \pm 9.65 and mean trait anxiety score of 53.5. In group $A$, the mean state anxiety score was $36.7 \pm 8.04$, and the mean trait anxiety score was $47.3 \pm 9.6$. The anxiety levels of the patients in group $B$ were significantly higher than anxiety levels of the patients in group $A(p<0.00 \mathrm{l})$.

Table 2. Comparison of operations according to groups

\begin{tabular}{lccc}
\hline Variables & Group A & Group B & p \\
\hline $\begin{array}{l}\text { Surgical approach, n (\%) } \\
\quad \text { Thoracotomy }\end{array}$ & $148(80.9)$ & $20(62.5)$ & $<0.00$ I \\
$\quad$ VATS & $35(19.1)$ & $12(37.5)$ & \\
Resection type, n (\%) & & & \\
$\quad$ Segmentectomy & $3(1.6)$ & $3(9.4)$ & 0.05 \\
Lobectomy & $142(77.6)$ & $23(71.9)$ & \\
Pneumonectomy & $38(20.8)$ & $6(18.8)$ & \\
\hline
\end{tabular}

VATS: Video-assisted thoracoscopic surgery.

Table 3. Evaluation of patients refuse operation

\begin{tabular}{lccc}
\hline Variables & $\begin{array}{c}\text { Refuse } \\
\text { operation }\end{array}$ & $\begin{array}{c}\text { Operated } \\
\text { in a } \\
\text { different } \\
\text { hospital }\end{array}$ & p \\
& & & \\
\hline $\begin{array}{l}\text { Comorbidity, n (\%) } \\
\text { No }\end{array}$ & $14(63)$ & $4(40)$ & 0.212 \\
Yes & $8(36.4)$ & $6(60)$ & \\
Surgical approach, n (\%) & & & \\
$\quad$ Thoracotomy & $12(55.5)$ & $8(80)$ & 0.168 \\
$\quad$ VATS & $10(45.5)$ & $2(20)$ & \\
Resection type, n (\%) & $1(4.5)$ & $2(20)$ & 0.308 \\
$\quad$ Segmentectomy & $16(72.7)$ & $7(70)$ & \\
$\quad$ Lobectomy & $5(22.7)$ & $1(10)$ & \\
$\quad \begin{array}{l}\text { Pneumonectomy } \\
\text { Anxiety situation, mean } \pm S D\end{array}$ & & & \\
$\quad$ State anxiety & $49.1 \pm 10.9$ & $46.5 \pm 9.1$ & 0.589 \\
$\quad$ Trait anxiety & $51.6 \pm 6.9$ & $54.4 \pm 8.9$ & 0.509 \\
\hline
\end{tabular}

VATS: Video-assisted thoracoscopic surgery; SD: Standard deviation.

\section{DISCUSSION}

With current advances in technology and improved quality of service, patients' expectations from the health sector are also increasing. As the quality of life improves, life expectancy is increasing, which also results in more people developing cancer. Moreover, both patient-to-doctor ratios and patients' expectations from hospitals are growing as well. Therefore, many hospitals conduct satisfaction surveys among their patients and healthcare personnel. ${ }^{7-9]}$ However, many issues, such as rising costs, demographic changes in societies, and growing demand increase hospital workloads, lead to problems in health services.

Patients' psychological status is affected by their demographics, clinical factors, age, comorbidities, cultural background, and treatment modalities. ${ }^{[2,4]}$ Parker $^{[4]}$ and Kadan ${ }^{[10]}$ reviewed patients' preoperative and postoperative depressive status and determined that comorbid diabetes mellitus was an important risk factor. In contrast to the literature, however, the patients in our study who refused surgery and the patients who accepted were comparable in terms of demographic characteristics, comorbidities, and clinical tumor stages. There were no statistically significant differences between the groups in these parameters.

Patient satisfaction is directly related to the conditions and quality of the hospital and the accessibility of facilities. ${ }^{\left[{ }^{\prime \prime}\right]}$ In our study, $15.6 \%$ of the patients who refused surgery were not satisfied with the hospital conditions. Since our hospital provides quality inpatient service, refusal was probably related to the hospital being crowded. VATS procedures and small resections were recommended more frequently for the patients who refused surgery. However, the size and surgical approach of the planned operations were not associated with patients' decisions to undergo surgery in our study.

The doctor-patient relationship also is also an important factor in treatment adherence. ${ }^{[12]}$ Many communication models have been identified between doctors and patients. Coulter et al ${ }^{[13]}$ argue that the collaborative model of doctor-patient communication is more beneficial and increases treatment adherence more than other types of communication. Boissy et al. ${ }^{[8]}$ reported that patient satisfaction is higher when doctors establish better communication with their patients. In our study, $21.9 \%$ of the patients refused surgery due to problems in the doctor-patient relationship. The patients stated that they could not obtain enough information from their doctors during the diagnosis process.

Patient satisfaction with the treatment and diagnosis process is very subjective. Thus, various analyses are conducted to evaluate them accurately. In this study, we used the STAI to assess the anxiety levels of the patients who refused treatment.

We found that patients who refused treatment had high state and trait anxiety scores. We attribute this to increased anxiety after being diagnosed with lung cancer. Hopwood et al. ${ }^{[14]}$ reported major depression in $50 \%$ of 
patients after receiving a lung cancer diagnosis. Gans ${ }^{[15]}$ also reported that biological and psychological factors contributed to patient depression. This state of depression and anxiety affects a patient's adherence to treatment. We also found a significant difference in anxiety level between patients who refused surgery and the patients who agreed to surgery $(p<0.00 \mathrm{l})$. Patients who exhibit symptoms of depression or anxiety during the period between diagnosis and surgery can overcome this psychological distress only if the diagnosing physician talks to them about the nature of their disease. This facilitates the patient's psychosocial adaptation following diagnosis, and psychologically prepares them for surgery. In our study, patients who refused surgery had higher anxiety levels compared to the patients who accepted surgical treatment. The main feature distinguishing our study from previous studies of anxiety and satisfaction in similar patient groups is that we evaluated patients who refused treatment. To our knowledge, there are no studies in the literature investigating reasons for refusing surgical treatment among lung cancer patients.

\section{Limitations}

The main limitations of this study are that it was retrospective and included a small number of patients. Another limitation is that the patients' preoperative anxiety symptoms could not be analyzed. The inability to conduct preto postoperative comparisons precluded an evaluation of changes in the patients' psychology.

\section{CONCLUSION}

In conclusion, our findings suggest that the main reason patients refuse surgical treatment is increased anxiety following diagnosis. We believe that the doctor-patient relationship is the essential factor in patients' adherence to treatment; therefore, improving communication and providing psychological support when necessary will facilitate treatment adherence.

Ethics Committee Approval

Approved by the local ethics committee.

Peer-review

Internally peer-reviewed.

Authorship Contributions

Concept: C.B.S., V.Y., C.I.K.; Design: S.I.D., C.B.S., K.K.; Supervision: C.B.S., V.K., S.B.; Fundings: C.B.S.; Materials: M.A.B., C.A.; Data: C.B.S., V.Y., C.I.K.; Analysis: C.B.S., K.K.; Literature search: C.B.S., V.Y., C.I.K.; Writing: S.I.D.,
C.B.S., K.K.; Critical revision: M.A.B., C.A.

Conflict of Interest

None declared.

\section{REFERENCES}

1. Sezen CB, Gokce A, Kalafat CE, Aker C, Tastepe AI. Risk factors for postoperative complications and long-term survival in elderly lung cancer patients: a single institutional experience in Turkey. Gen Thorac Cardiovasc Surg 2019;67:442-9. [Crossref]

2. Holland J. NCCN practice guidelines for the management of psychosocial distress. Oncology 1999;13:113-47.

3. Carr D, Goudas L, Lawrence D, Pirl W, Lau J, DeVine D, et al. Management of cancer symptoms: pain, depression, and fatigue. Evid Rep Technol Assess (Full Rep) 2002;61:368-74. [Crossref]

4. Park S, Kang CH, Hwang Y, Seong YW, Lee HJ, Park IK et al. Risk factors for postoperative anxiety and depression after surgical treatment for lung cancer. Eur J Cardiothorac Surg 2016;49:e16-21.

5. Spielberger CD, Gorsuch RL, Lushene RE. STAI. Cuestionario de Ansiedad Estado-Rasgo. Madrid, Man 1993;6.

6. Öner N, LeCompte WA. Durumluk sürekli anksiyete envanteri el kitabı. İstanbul: Boğaziçi Üniversitesi Yayınları 1985.

7. Graham B, Green A, James M, Katz J, Swiontkowski M. Measuring patient satisfaction in orthopaedic surgery. J Bone Joint Surg Am 2015;97:80-4. [Crossref]

8. Boissy A, Windover AK, Bokar D, Karafa M, Neuendorf K, Frankel $\mathrm{RM}$, et al. Communication skills training for physicians improves patient satisfaction. J Gen Intern Med 2016;31:755-61. [Crossref]

9. Tsai TC, Orav EJ, Jha AK. Patient satisfaction and quality of surgical care in US hospitals. Ann Surg 2015;261:2-8. [Crossref]

10. Kadan-Lottick NS, Vanderwerker LC, Block SD, Zhang B, Prigerson HG. Psychiatric disorders and mental health service use in patients with advanced cancer: a report from the coping with cancer study. Cancer 2005;104:2872-81. [Crossref]

11. Wright JD, Tergas AI, Ananth CV, Burke WM, Chen L, Neugut $\mathrm{AI}$, et al. Relationship between surgical oncologic outcomes and publically reported hospital quality and satisfaction measures. J Natl Cancer Inst 2015;107:1-9. [Crossref]

12. Özçakır A. Hekim-hasta ilişkisi: karar verme sürecinde hastanın yeri. Turkiye Klinikleri J Med Sci 2004;24:411-5.

13. Coulter A. Paternalism or partnership? Patients have grown up-and there's no going back. BMJ 1999;319:719-20. [Crossref]

14. Hopwood P, Stephens RJ. Depression in patients with lung cancer: prevalence and risk factors derived from quality-of-life data. J Clin Oncol 2000;18:893-903. [Crossref]

15. Ganz PA, Haskell CM, Figlin RA, La Soto N, Siau J. Estimating the quality of life in a clinical trial of patients with metastatic lung cancer using the Karnofsky performance status and the Functional Living Index--Cancer. Cancer 1988;61:849-56. [Crossref] 


\section{Küçük Hücreli Dışı Akciğer Kanseri Nedeniyle Operasyon Planlanan Hastaların Tedaviyi Kabul Etmeme Nedenleri ve Anksiyete Durumlarının Değerlendirilmesi}

Amaç: Bu çalışmada, hastanemizde küçük hücreli dışı akciğer kanseri tanısı konulan ve multidisipliner konsey kararı ile operasyon planlanan ancak ameliyat olmayı reddeden hastaların, neden ameliyat olmak istemediklerini ve anksiyete durumlarını inceledik.

Gereç ve Yöntem: Hastanemiz onkoloji konseyi tarafından değerlendirilerek ameliyat önerilen 223 hasta geriye dönük olarak incelendi. Grup A'da cerrahi tedaviyi kabul eden hastalar ve Grup B'de cerrahi tedaviyi reddeden hastalar yer almaktaydı. Tüm hastaların anksiyete düzeyleri "State-Trait Anxiety Inventory" (STAI) kullanılarak değerlendirildi.

Bulgular: Grup B'deki hastaların anksiyete düzeyleri Grup A'ya göre anlamlı derecede yüksekti $(p<0.001)$. Grup B'deki hastaların 22 'si (\%68.8) cerrahi tedaviyi hiç kabul etmezken, 10 'u (\%31.3) başka merkez de ameliyat olmayı tercih etmişti. Cerrahi tedaviyi kabul etmeme nedenleri incelendiğinde 20 hastanın (\%62.5) cerrahi riski yüksek bulması nedeniyle, yedi hastanın (\%21.9) doktorun bilgilendirmesini yetersiz bulması nedeniyle, beş hastanın (\%15.6) ise hastanenin imkanlarını beğenmemesi nedeniyle ameliyatı kabul etmediği bulundu.

Sonuç: Sonuç olarak hastaların cerrahi tedaviyi kabul etmeme nedenleri içerisinde en önemli kısmın hastaların tanı sonrasında ruhsal olarak meydana gelen artmış anksiyete durumu olduğunu saptadık. Hasta-hekim iletişiminin ise hastaların tedaviye olan uyumdaki en önemli faktördür.

Anahtar Sözcükler: Akciğer kanseri; anksiyete durum; cerrahi; göğüs cerrahisi; tedaviyi reddetme. 